\title{
Solitary Metastasis of Renal Cell Carcinoma to the Third Ventricle Mimicking a Colloid Cyst: Case Report
}

\section{Renal Hücreli Karsinomun Kolloid Kist Görünümünü Taklit Eden 3. Ventrikül Metastaz: Olgu Sunumu}

\author{
Mete KARATAY ${ }^{1}$, Ender KOKTEKIR ${ }^{2}$, Yavuz ERDEM ${ }^{1}$, Haydar CELIK $^{1}$, Mehmet Akif BAYAR ${ }^{1}$ \\ ${ }_{1}^{1}$ Ankara Education and Research Hospital, Department of Neurosurgery, Ankara, Turkey \\ ${ }^{2}$ Selcuk University, School of Medicine, Department of Neurosurgery, Konya, Turkey
}

Corresponding Author: Ender KOKTEKIR / E-mail: enderkoktekirnrs@hotmail.com

\begin{abstract}
Colloid cysts are the most common third ventricle lesions and metastasis to this area is rare. We presented a case of solitary metastasis from a renal cell carcinoma to the third ventricle choroid plexus mimicking a colloid cyst. A 53-year-old man, who had a history of renal cell carcinoma 12 years ago, was operated for single third ventricle lesion and hydrocephalus via a transcallosal approach. Total removal could not be performed due to intraoperative massive bleeding. Histological examination revealed a metastatic renal cell carcinoma. The patient died on the postoperative $13^{\text {th }}$ day because of bleeding from the residual tumor. Stereotactic radiosurgery and ventriculoperitoneal shunting might be favorable in such cases in order to avoid serious complications.
\end{abstract}

KEYWORDS: Renal cell carcinoma, Choroid plexus, Third ventricle, Metastasis, Colloid cyst

Öz

Üçüncü ventrikülün en sık görülen lezyonları kolloid kistlerdir ve bu bölgeye metastazlar çok nadir gözlenir. Biz, görünümü kolloid kiste benzeyen, renal hücreli karsinomun 3. ventrikül koroid pleksusuna metastazı olan bir olguyu bildirdik. Elli üç yaşında, 12 yıl önce renal hücreli karsinom tanısı alan, erkek hasta; tek 3. ventrikül metastazı ve hidrosefali nedeni ile opere edildi. Aşırı intraoperatif kanama nedeni ile tümör tamamen çıkartılamadı. Histolojik sonuç, renal hücreli karsinom metastazı idi. Hasta rezidüel tümör içerisine ve oluşan kanama nedeniyle ameliyat sonrası 13. günde öldü. Bu tür hastalarda cerrahi girişimin yaratacağı ciddi komplikasyonları engellemek için stereotaktik radyocerrahi ve ventriküloperitoneal şant tedavisi daha uygun olabilir.

ANAHTAR SÖZCÜKLER: Renal hücreli karsinom, Koroid pleksus, 3. ventrikül, Metastaz, Kolloid kist

\section{INTRODUCTION}

Cerebral metastases are by far the most common intracranial tumors in adults. Involvement of the ventricular system is not common and it is almost always associated with multiple brain metastases when it occurs $(1,3,4)$. Solitary metastasis to the ventricular system and especially to the third ventricle is very rare $(6,7,9)$. The most common solitary lesions of the third ventricle are colloid cyst and choroid plexus papilloma (5). We present a rare case of solitary third ventricle choroid plexus metastasis from a renal cell carcinoma mimicking a third ventricle colloid cyst. The prognosis of these lesions and treatment options are discussed with the review of the literature.

\section{CASE REPORT}

A 53-year-old man was admitted with sudden headache, vomiting and acute deterioration of cognitive functions. Medical history revealed that the patient had received left nephrectomy, radiotherapy (1 dose of $50 \mathrm{~Gy}$ ) and chemotherapy (oral 5-fluorouracil) for renal cell carcinoma 12 years ago. There was no recurrence or extrarenal metastasis detected in annual oncology control. GCS was 14 (E4M6V4) at the time of admission. There was no cranial nerve deficit or motor weakness on neurological examination. Computed tomography (CT) scan revealed an isodense lesion in the third ventricle (Figure 1). Magnetic resonance imaging (MRI) showed a heterogeneously enhancing, round shaped mass lesion $(22 \times 19 \times 27 \mathrm{~mm})$ in the third ventricle associated with mild hydrocephalus (Figure 2). The patient was operated via an interhemispheric transcallosal approach. Total tumor resection could not be performed due to intraoperative massive bleeding from the well vascularized tumor. Postoperative GCS was 14 on the first day. In the postoperative third day the patient neurologic status was worsened and the GCS abruptly dropped to 4 (E1, V1, M2). CT scanning demonstrated the massive intraventricular bleeding from the residual tumor (Figure 3). Bilateral ventricular drainage was inserted immediately. The patient neurological findings 
did not improve and he died on the postoperative 13th day. The pathological examination consisted with clear cell renal carcinoma metastasis (Figure 4).

\section{DISCUSSION}

The most common tumors that cause a cerebral and cerebellar metastasis are lung, breast and skin cancer $(2,5,6)$. However, the frequency of the primary tumors causing a ventricle metastasis is different. Our literature review showed that the most common cause of the ventricle metastasis was renal cell carcinoma (RCC) of the kidney followed by lung, colon and thyroid carcinomas.

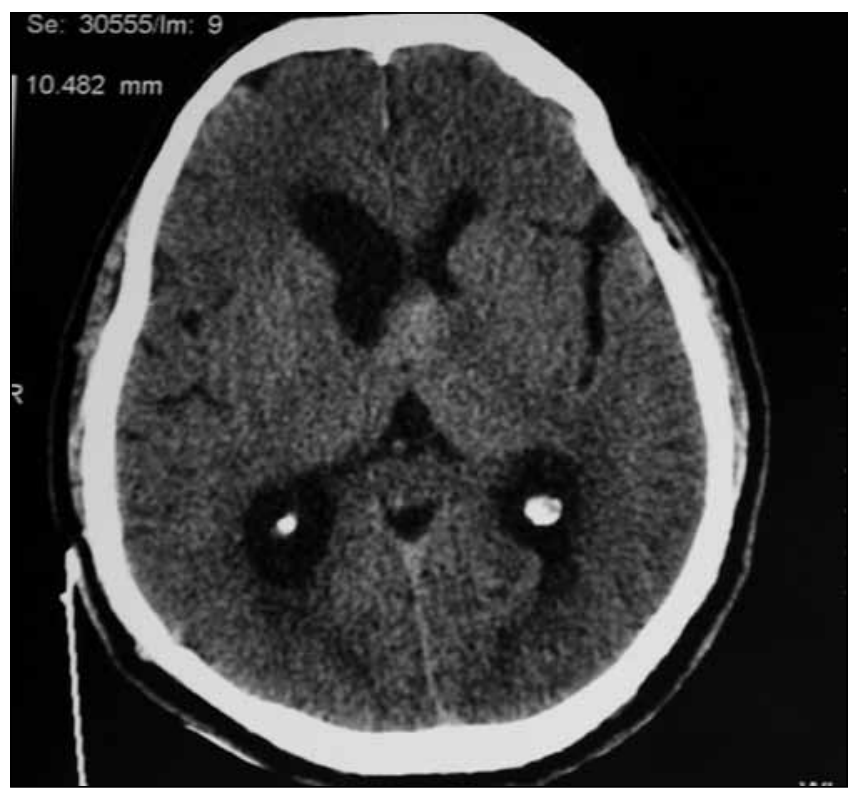

Figure 1: Preoperative CT scan is showing the isodense lesion in the third ventricle and ventricular dilatation.

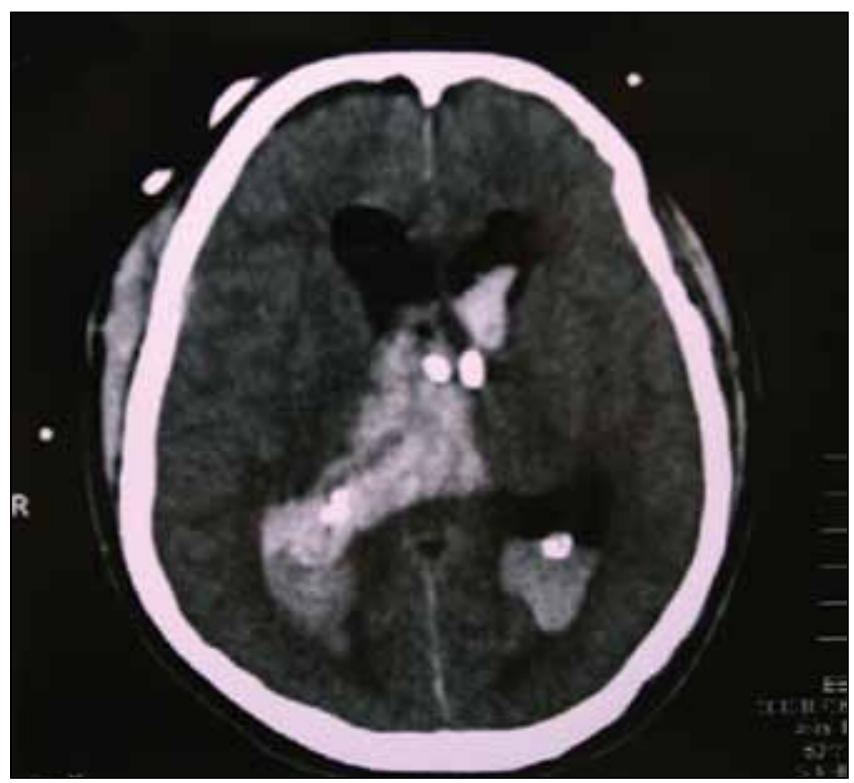

Figure 3: Postoperative CT scan is showing the intraventricular bleeding from residual tumor.
Ventricular system tumors account for less than $1 \%$ of intracranial lesions and the ventricular metastases represent approximately $\% 2$ of all intraventricular tumors $(3,4)$. However, the ventricular system involvement is almost always associated with multiple brain metastases and the incidence of the solitary metastasis is not known. Our literature review revealed only 39 cases of solitary metastasis in the ventricular system. The most common locations were as follows: 30 cases in lateral ventricles (76.9\%), 7 cases including the presented case in third ventricle (17.9\%) and two cases in fourth ventricle (5.1\%).

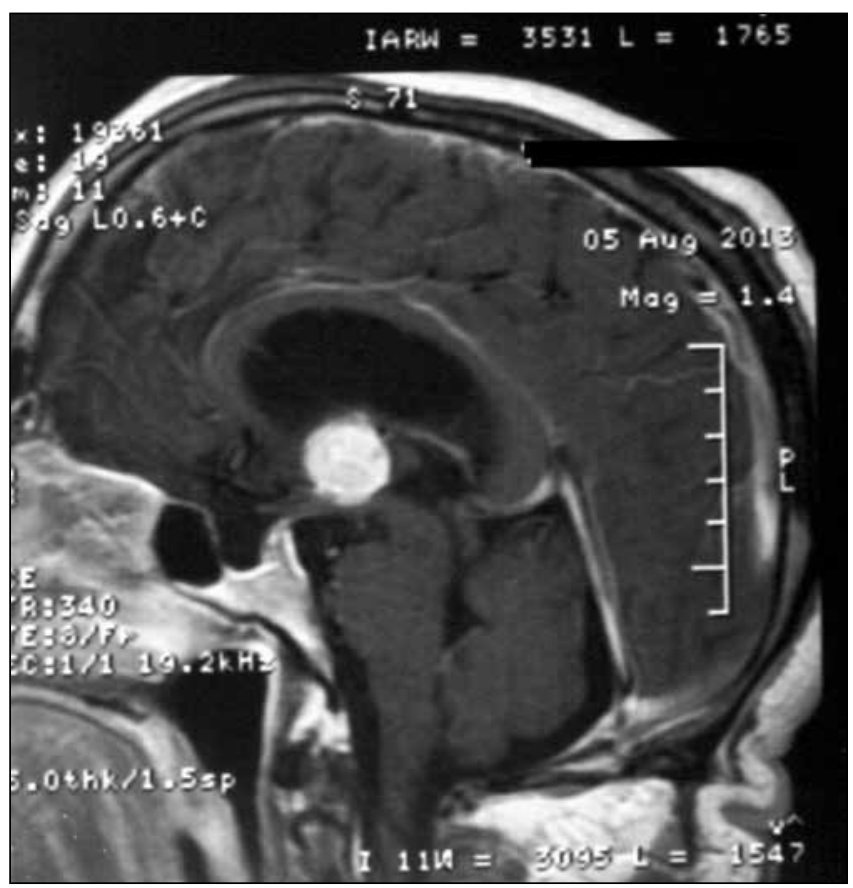

Figure 2: Sagittal cranial MRI is showing the hyperintense lesion of the third ventricle which mimicking a colloid cyst.

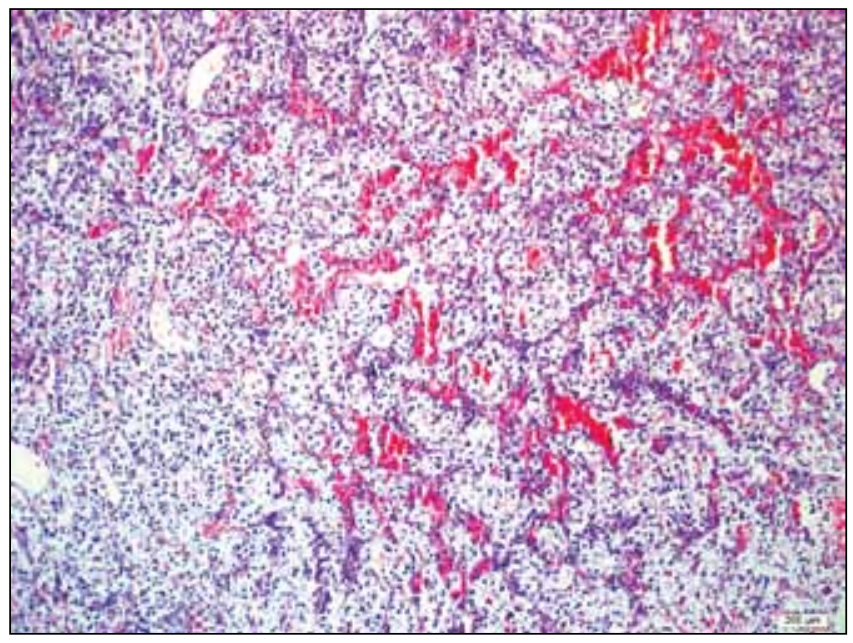

Figure 4: Metastatic clear cell renal carcinoma: proliferation of anaplastic epithelial cells with clear cytoplasm, and hyperchromatic, irregular nuclei, displayed in sheets detached by fine conjunctive septa including capillaries. 
Tumors of the third ventricle may arise from three different regions including periventricular, sellar or suprasellar location with expansion to the third ventricle, arising from neural structures forming the third ventricle and within the ventricle arising from the choroid plexus $(5,6,7)$. The latter one is less frequently seen and most of them are benign lesions such as colloid cysts and choroid plexus papillomas. Although the choroid plexus is highly vascularized and theoretically is vulnerable to metastasis, a few cases have been reported ( 2 , $4,6,7,9)$. In those cases it is very rare for metastases to mimic a colloid cyst as in our case and to our knowledge only three cases have been previously reported.

The primary tumor's histological type appears to be the most important factor regarding the frequency and pattern of intracranial extension. According to autopsy studies, it is estimated that approximately one-third to one-fourth of the patients harboring cancer will have brain metastasis. Nowadays, with the advancing imaging techniques, intracranial metastasis can be detected in most cancer patients even they are asymptomatic. The other organ metastases are usually seen in those cases. However, it has been shown that the late intracranial metastases might be seen even decades after the first diagnosis of RCC especially in slowly progressive type $(3,4,9)$. Although, it has been reported that the abdominal and thoracal metastases from the RCC frequently are seen concomitantly in such cases $(5,6,7)$; in our case, the metastasis occurred 12 years after nephrectomy and the radiologic studies disclosed no other lesions.

The treatment strategies of intracranial metastasis are challenging. The number of metastases, the relationship of the tumor with the eloquent areas, the patient's clinical course, presence of extracranial metastasis and histological features of the cancer primarily effect the selection of the treatment options. Surgical resection is usually recommended for most of the solitary metastases in patients with good clinical condition as in our case (10). However, Sheehan et al. found that the stereotactic radiosurgery for treatment of RCC metastases to the brain provides local tumor control in approximately $96 \%$ of patients (8). In the presented case, the preoperative diagnosis of the lesion was colloid cyst and surgical resection was attempted. Due to the narrow corridor of transcallosal approach and the massive bleeding from the tumor after the biopsy, total resection could not be performed and the patient died on the postoperative 13th day. The cause of death in our patient was the re-bleeding of the residual tumor. However, if we suspected the RCC metastases preoperatively our treatment strategy would be the Gamma-Knife surgery and ventriculoperitoneal shunting.

\section{CONCLUSION}

Solitary metastasis of renal cell carcinoma to the third ventricle choroid plexus is an uncommon condition but it should be taken into account as a differential diagnosis of the colloid cysts in patients who have a systemic cancer history. In such cases, total resection should be attempted whenever is possible due to risk of the postoperative bleeding from the residual tumor. However, stereotactic radiosurgery might be considered as a treatment option rather than surgical resection in deeply located tumors in order to avoid serious complications.

\section{REFERENCES}

1. Bademci G. Extremely delayed renal cell carcinoma metastasis mimicking convexity meningioma. Turk Neurosurg18:400-403, 2008

2. Kitagawa $Y$, Higuchi $F$, Abe $Y$, Matsuda $H$ Kim P, Ueki K: Metastasis to the Choroid plexus from thyroid cancer: Case report. Neurol Med Chir 53: 832-836, 2013

3. Leach JCD, Garrot H, King JAJ, Kaye AH: Solitary metastasis to the choroid plexus of the third ventricle mimicking a colloid cyst: A report of two cases. J Clin Neurosci 11:521-523, 2004

4. Matsumura $\mathrm{H}$, Yoshimine T, Yamamoto $S$, Maruno $M$, Hayakawa T, Ono Y, Kondoh N, Namiki M: Single solitary metastasis of the slowly progressive type of renal cell carcinoma to the choroid plexus--case report. Neurol Med Chir 37: 916-919, 1997

5. Menon G, Nair SN, Baldawa SS, Rao RB, Krishnakumar KP, Gopalakrishnan CV: Choroid plexus tumors: An institutional series of 25 patients. Neurol India 58: 429-435, 2010

6. Raila FA, Bottoms WT Jr, Fratkin JD: Solitary choroid plexus metastasis from a renal cell carcinoma. South Med J 19: 1159-1162, 1998

7. Sadatomo T, Yuki K, Migita K, Taniguchi E, Kodama Y, Kurisu K: Solitary brain metastasis from renal cell carcinoma 15 years after nephrectomy: Case report. Neurol Med Chir 45:423-427, 2005

8. Sheehan JP, Sun MH, Kondziolka D, Flickinger J, Lunsford LD: Radiosurgery in patients with renal cell carcinoma metastasis to the brain: Long-term outcomes and prognostic factors influencing survival and local tumor control. J Neurosurgery 98: 342-349, 2003

9. Tomiyama A, Nakayama H, Aoki K, Ueda M: Solitary metastasis of renal cell carcinoma to the third ventricular choroid plexus with rapid clinical manifestation by intratumoral hemorrhage. Neurol India 56(2):179-181, 2008

10. Wronski M, Arbit E, Russo P, Galicich JH: Surgical resection of brain metastases from renal cell carcinoma in 50 patients. Urology 47(2):187-193, 1996 